УДК 620.178.4/.6:62-45:538.911:519.688

Tatarchuk T. V. PhD Tech., associate professor of Physics Department of National University «Zaporizhzhia Polytechnic», Zaporizhzhia, Ukraine, e-mail: tanko.ho1@gmail.com

Kravchuk Yu. S. $\quad$ specialist of the highest category, senior lecturer, Zaporozhye Aviation College named after O.G. Ivchenko, Zaporizhzhia, Ukraine, e-mail:kravchuk@zac.org.ua

Pelykh V. P. $\quad$ student of Kharkiv National Aerospace University named after M. Y. Zhukovsky «Kharkiv Aviation Institute», Kharkiv, Ukraine, e-mail: venator.verba@gmail.com

\title{
USE OF ADDITIVE TECHNOLOGIES IN THE MANUFACTURE OF CENTRAL IMPACTORS
}

Purpose. Analysis of methods of manufacturing centrifugal blades by $3 D$ printing methods on the example of a modernized cooling system of the AI-450M engine of the Mi-2MSB helicopter.

Research methods: calculation method of finite elements, analytical.

Results. Studies have shown that the use of layer-by-layer printing technology of the centrifugal wheel of the cooling system provides the following opportunities and improvements:

- reduce the percentage of rejection of finished products by 8-9 times;

- reduce material consumption by 300-400\%;

- increase the speed of production, experiments and testing the manufacture of working elements through the development of new technologies for rapid production (rapid fabrication);

- easy printing of previously "impossible" geometry.

The analysis of possible types of manufacturing of working centrifugal wheel and the calculated estimation of thermodynamic parameters in the course of step-by-step drawing of layers of metal is carried out. The problem of a large percentage of defects in the process of classical-mechanical milling of blades was solved by changing the type of production to additive one.

Scientific novelty. In today's world, the spread of CAD / CAM / CAE / PLM technologies and the accumulation of a wide library of materials open up a large number of new and more efficient, in terms of economy and quality, methods of manufacturing components and units. Following the example of such giants in the production of aircraft engines as Rolls-Royce Motor, General Electric and Pratt \& Whitney, it is clear that the use and development of the latest methods of three-dimensional printing is appropriate.

Practical value. The obtained results are important in the further process of production and modernization of Mi-2 helicopter of all modifications with the latest engines, as well as for projects for the development of helicopter construction in Ukraine - MCБ-2 "Hope", MCБ-6 "Otaman", MCБ-8 and others. The ability to increase the efficiency of manufacturing the main working elements - blades allows you to reduce the cost of components, their further repair, operation. The most important factor is to increase reliability, as in the manufacture reduces the likelihood of defects, which will not be detected at the stages of intermediate and final control.

Key words: additive technologies (AT), 3D printing, layer-by-layer extension, centrifugal wheel $(\mathrm{CW})$, finite element method (FEM), cooling system (CS), modernization, air system, pneumatic system, aircraft compressor.

\section{Introduction}

Working rotary elements currently have a complex geometry, which is difficult, and in most cases even impossible to transfer geometric dimensions. In their manufacture, working tools perform complex spatial movements in 6 degrees of freedom. Even in the case of using $\mathrm{CNC}$ machines, the manufacturing process is delayed and sometimes can not even be completed, due to the impossibility of supplying the cutting tool to the workpiece without the risk of its breakdown [8].

One of the most promising areas of development of modern engineering is the development of new technologies for rapid production of products (rapid fabrication). The essence of such technologies is the layer-by-layer construction of products from powder material on the basis of CAD-models - models whose three-dimensional geometry is described in digital form, using solid-state modeling programs (SolidWorks, CATIA, ProE, AutoCAD, etc.).
When setting the geometry in the form of reference points, lines and surfaces (frame model) and its subsequent translation into the most common stl., Step., X_t. or another format, which can then be cut with slice-sulfurwe get a layered image of each intermediate section, which is set by the boundary splines and baked by lasers along the trajectories.

Currently, the most common elements with complex geometry are the impellers of centrifugal fans, pumps and compressors [2]. Since these elements are structurally monolithic, and the number of blades that need to be processed exceeds 10 , their manufacture by metal subtraction methods is impractical [7].

Additive methods of production of centrifugal blades and impellers of compressors, pumps and fans will become more and more popular every year, they can be found in the manufacture of high and low pressure compressors for air- 
craft and ground engines, air pneumatic and hydraulic pumps of responsible systems, power plants, cooling fans [1].

\section{Analysis of research and publications}

Considering the process of development of methods of production of elements of pumps, fans and compressors, special attention is paid to the period 2010-2020 [3-6], in which the active development of additive technologies began, the literature of this period is the newest, relevant and has the largest authority. Most scientists and authors note the special attention of the giants of the aviation and engine industry in the field of spatial printing. "Prospects for the use of additive technologies in the creation of aerospace and rocketry" - the result of an in-depth analysis of the latest trends, means of saving and increasing reliability in the production of the most loaded pneumatic and hydraulic systems.

Spatial printing is usually appropriate for the manufacture of parts of complex geometry with a large number of planes and thin-walled elements in the production of small and medium batches, and less appropriate for parts with a simple structure and mass or multi-batch production [3].

Thus, this paper presents a modernized centrifugal fan of the Mi-2 helicopter and performed CAD calculations (temperature, deformation, mechanical stress) in the most important section for this part, provided it is manufactured using additive technologies.

\section{Goal of the work}

The main purpose of this work is the analysis of methods of manufacturing centrifugal blades by $3 \mathrm{D}$ printing methods on the example of the modernized cooling system of the AI-450M engine of the Mi-2MSB helicopter.

Increasing production productivity, and as a consequence of reducing the cost of manufacturing working blade parts and assemblies is possible in the following ways:

- organization of production;

- increase of a series;

- use of more advanced equipment;

- mechanization of the cycle;

- the use of fundamentally different production methods that save time of equipment operation, material consumption and other indicators of production.

Changing the organization of production is not always possible within the established type of management. This requires a lot of money and a lot of work with management. The organization of production is a matter for coaches and managers, from the point of view of technical workers this issue is not considered.

Increasing the production series is not an effective way, because in some cases, it is not appropriate due to low demand for goods, or experimental / experimental type of production, which is mandatory in the initial stages of production. Particular attention should be paid to the fact that in the field of aircraft construction - mass production is a rare phenomenon and is not permanent. The convenience of the additive method is the ability to manu- facture parts and assemblies in series of up to 100 and more than 10,000 with a relatively equal cost per unit of goods.

The use of more advanced equipment is always a large pile of economic calculations of production costs, calculation of series payback ratios, cost-effectiveness ratios of capital investments, payback period indicators, which in many cases will indicate the inexpediency of purchasing new equipment. It is also unprofitable to install new tools for small series of production, which also closes the possibility of experimental and small-scale production.

Mechanization of the production cycle can significantly reduce the percentage of manual labor, increase the pace of production, allows you to go to a parallel or series-parallel cycle, but can be used effectively only in mass production.

Due to all these factors, the most logical way is to find the latest production methods that will contain the advantages of the classical method of machining, but will be able to give the necessary increase in productivity.

After studying the ways of production of the world's production giants, it was found that the methods of spatial printing are not only used, but gradually replace the classic types of tools [5].

\section{Presentation of the basic material and analysis of the obtained results}

After the remotirization and replacement of the GTD-350 with newer AI-450M-P, which increased the capacity, the heat output also increased. The fan assembly has not been structurally changed, the cooling system designed for less powerful engines began to work in more complex conditions. Productivity began to be lacking both for cooling the STG-9M starter generators and for blowing the flanges connecting the shafts of the main gearbox and motors (or idling clutches, if any).

Since the unit operates at a nominal $8000 \mathrm{rpm}$, it is possible to use a centrifugal fan type. This design change gives a big increase in the productivity of pumping cold heated air to hot units.

As initial data, to test the feasibility and feasibility of the additive method, were selected: the geometry of the impeller of the centrifugal fan unit of the helicopter MSB-2, wheel material titanium Ti64 (granular) (the most common fine powder with close mechanical physical and operational characteristics to the original titanium alloy). Obviously, to reduce the cost of the experiment, it is advisable to create a virtual copy of the product, so a spatial model was built, which was then transformed into $\mathrm{x} \_\mathrm{t}$ format for calculation in the FEM system, and in stl to analyze the success of slicer and print.

In fig. 1. The modernized centrifugal fan of the Mi-2 helicopter is presented. As a result of calculations the ready geometry of the main and splitter blades was received. All other wheel elements were added to CAD COMPASS 3D. See the final geometry in Fig. 2.

To reduce the cost due to additive production, we calculate the necessary parameters for two cases, production by the method of spatial printing, and machining. 
Material savings are the ratio of the amount of alloy used for milling and drilling to the amount of material that will be converted into printing powder:

$$
K_{M}=\frac{M_{M}}{M_{A}}=\frac{59,971}{15,169}=3,95,
$$

where $M_{M}$ - the mass of material used in the manufacture of mechanical means, $\mathrm{kg}$;

$M_{A}$ - the mass of material used in the manufacture of the additive method, $\mathrm{kg}$.

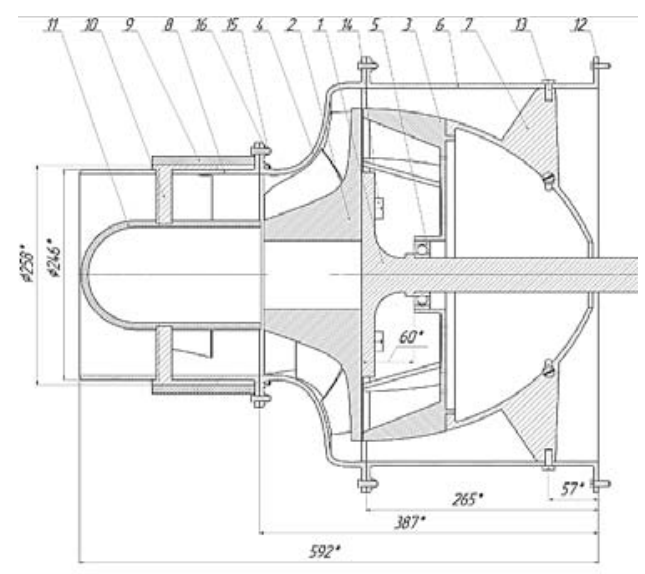

Fig. 1. Upgraded explosive helicopter Mi-2:

1 - shaft; 2 - centrifugal wheel; 3 - stator disk; 4 - diffuser; 5 - ceramic bearing; 6 - housing; 7 - diffuser cone; 8 - fairing housing; 9 - casing; 10 - stator blade; 11 - fairing; 12 - bolt; 13 , 14 - screws; 15 - nut; 16 - washer

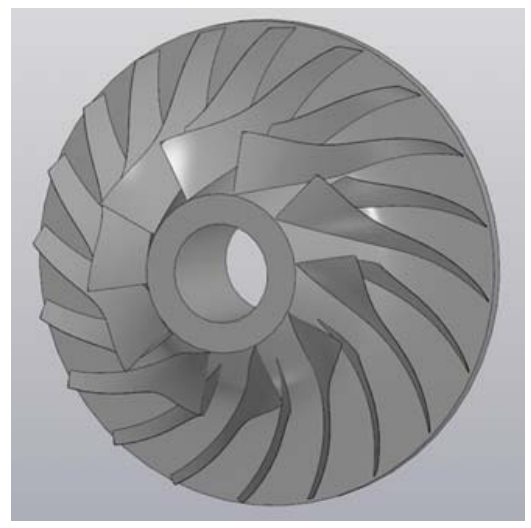

Fig. 2. 3D model of a working centrifugal wheel

That is, with the help of spatial printing you can save almost 4 times

Specific energy input:

$$
E_{L_{M}}=\frac{P_{M}}{V_{M}}=\frac{70000}{133269903}=0,0052,
$$

where $P_{M}$ - the amount of energy consumed during mechanical production, $\mathrm{kW}$;

$V_{M}$ - volume of material of the workpiece of the centrifugal wheel, $\mathrm{mm}^{3}$;

$$
E_{L_{A}}=\frac{P_{A}}{V_{A}}=\frac{45000}{3370964}=0,0133,
$$

where $P_{A}$ - the amount of energy consumed during production by the additive method, $\mathrm{kW}$;

$V_{A}$ - the volume of material required for printing the centrifugal wheel, $\mathrm{mm}^{3}$;

$$
\frac{E_{L_{A}}}{E_{L_{M}}}=\frac{0,0133}{0,0052}=2,557 .
$$

This indicates an increase in energy consumption in additive printing by $255 \%$.

The most important factor is the percentage of printing, from open sources it is known that the lack of stages from the workpiece to the final machined impeller is in the range of $75 \ldots 85 \%$ (in terms of triple curvature of the working surface and the number of blades more than 10). General Electric achieved a failure rate of $3 \ldots 10 \%$ for compressors of complex geometry.

The final efficiency is calculated by the formula:

$$
\begin{gathered}
C_{M}=\left(L_{M} \cdot M_{M}+P_{M} \cdot T_{M}\right) \cdot \Delta_{M}= \\
=(1200 \cdot 59,971+70000 \cdot 1,68) \cdot 5=947826,
\end{gathered}
$$

where $\bigsqcup_{M}$ - the price of the material used for the manufacture of $\mathrm{CW}$ by mechanical means;

$T_{M}$ - the price per unit of energy input in mechanical manufacturing;

$\Delta_{M}$ - the mass coefficient coefficient in mechanical production, $\mathrm{kg}^{-1}$.

$$
\begin{gathered}
C_{A}=\left(L_{A} \cdot M_{A} \cdot+P_{A} \cdot T_{A}\right) \cdot \Delta_{A}= \\
=(1800 \cdot 15,169+45000 \cdot 1,68) \cdot 1,05=108049,
\end{gathered}
$$

where $\bigsqcup_{A}$ - the price of the material used for the manufacture of $\mathrm{CW}$ by mechanical means;

$T_{A}$ - the price per unit of energy input in additive manufacturing; ing, $\mathrm{kg}^{-1}$.

$\Delta_{A}$ - the mass coefficient for additive manufactur-

$$
\frac{C_{M}}{C_{A}}=\frac{947826}{108049}=8,77 .
$$

That is, the average increase without taking into account the costs of administrative services, sales, etc. is $877 \%$. The comparison in the first approximation indicates a significant increase in manufacturing productivity, compared with the original method.

With the help of FEM analysis we determine the possibility of printing the geometry of the wheel on the simplest printers. Analyzing the obtained results, we can conclude that it is possible to achieve the required values of quality and economy of the material, the details of which are made by the additive method. Among the features of creating a grid are the creation of a very small grid over the entire volume of the part, the creation of the base on which the part will be built and the creation of 
reinforcing supports (due to the complex geometry of the main blades, the angle is greater than $70{ }^{\circ} \mathrm{C}$ ). In fig. 3 presents a grid of finite elements for thermodynamic calculation, and in table. 1 - initial calculation parameters.

Table 1 - Initial calculation parameters

\begin{tabular}{|c|c|}
\hline Indicator & Parameter \\
\hline Sintering temperature & $1604^{\circ} \mathrm{C}$ \\
\hline NS temperature & $22^{\circ} \mathrm{C}$ \\
\hline Powder dimensions & $0,4-0,8$ \\
\hline Powder material & Ti64 \\
\hline Impeller weight & $15,169 \mathrm{~kg}$ \\
\hline Pressure in the chamber & $110000 \mathrm{~Pa}$ \\
\hline Maximum material stress & $1000 \mathrm{~N} / \mathrm{mm}^{2}$ \\
\hline Base material & $40 \mathrm{XC}$ \\
\hline
\end{tabular}

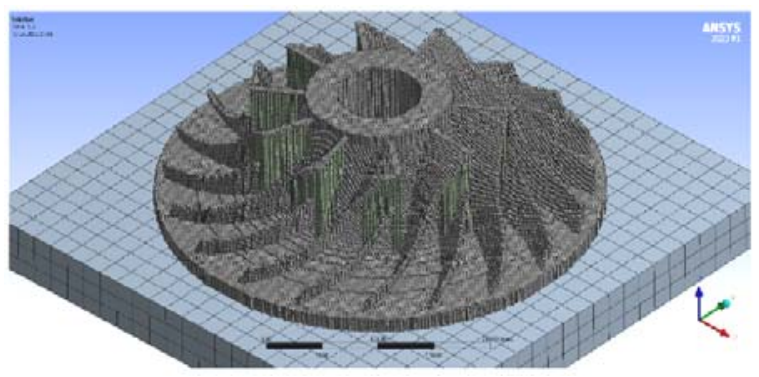

Fig. 3. Finite element grid for thermodynamic calculation

The calculation of temperature loads is carried out in the program Ansys Transient Thermal. The input data for the calculation were: powder material (Ti64), ambient temperature (taken under standard conditions), parameters of the laser installation (the simplest laser installation) and other reference data. The dimensions of the powder are $0.4 \mathrm{~mm}$. Operating sintering temperature $1604{ }^{\circ} \mathrm{C}$ (Fig. 4). Each layer of powder is sintered and then cooled to an ambient temperature of $22^{\circ} \mathrm{C}$.

The calculation of mechanical loads in the printing process is carried out in the program Ansys Static Structural. The input data were the values obtained in the Transient Thermal module. As a result of the calculation, error values due to temperature stresses in the cross sections were obtained.

The largest defect is obtained in the cross section of the supports (Fig. 5), which in the maximum values is equal to $2.1 \mathrm{~mm}$. The error in the cross section of the blade at all stages of printing does not exceed $1 \mathrm{~mm}$, which is less than the required tolerance $(3 \mathrm{~mm})$. Because the supports are removed after printing, an error of 2.1 $\mathrm{mm}$ can be neglected.

An important indicator is the shear stress in the cross section during printing. The maximum allowable shear stress for Ti64 is about $1000 \mathrm{~N} / \mathrm{mm}^{2}$, in the printing process the shear stress in the section is kept within 550 $\mathrm{N} / \mathrm{mm}^{2}$, which is almost twice less than the allowable. At critical points, the voltage reaches $814 \mathrm{~N} / \mathrm{mm}^{2}$ units, which allows us to consider the printing process safe for internal loads. Figures 5-7 are presented in a scale of 20:1 for the convenience of lining the places of deformation. See the on-shear field in Figure 6.

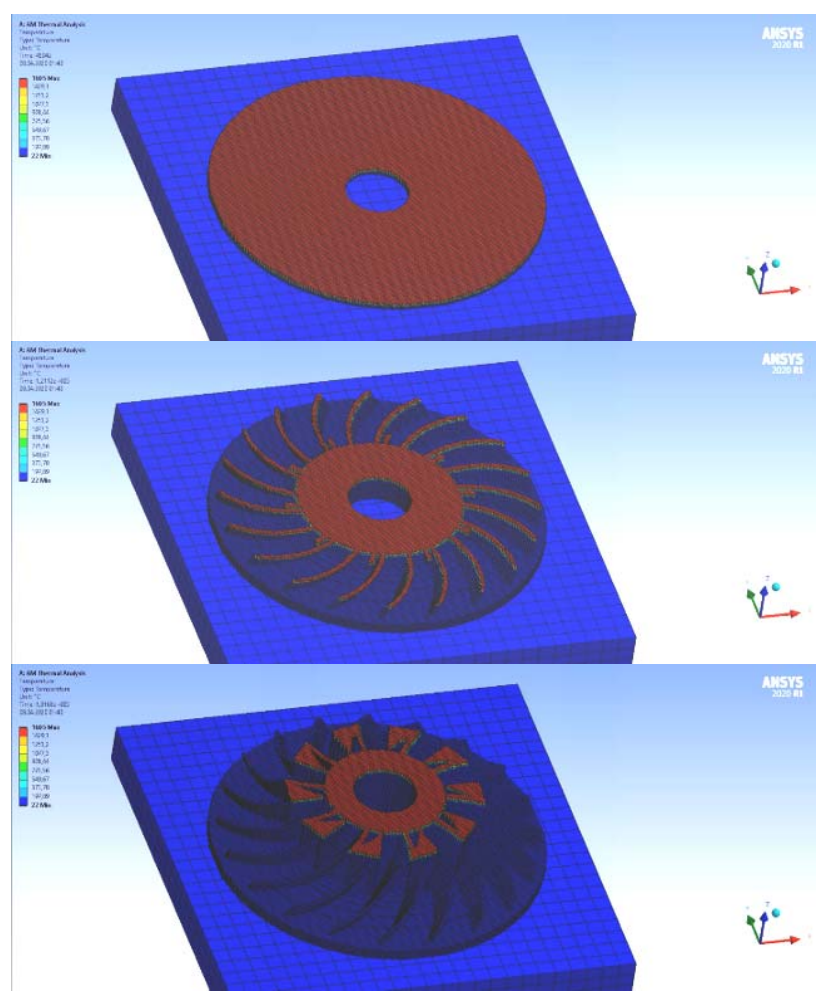

Fig. 4. Temperature field at the beginning in the middle and end of the sintering process of the wheel

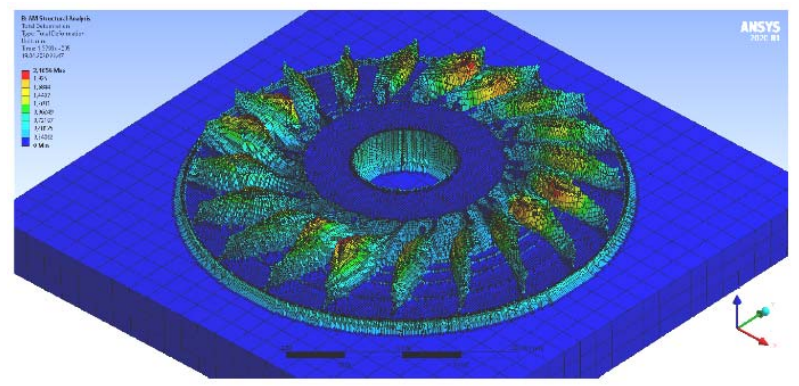

Fig. 5. Defect field as a result of thermal loads in the most loaded section

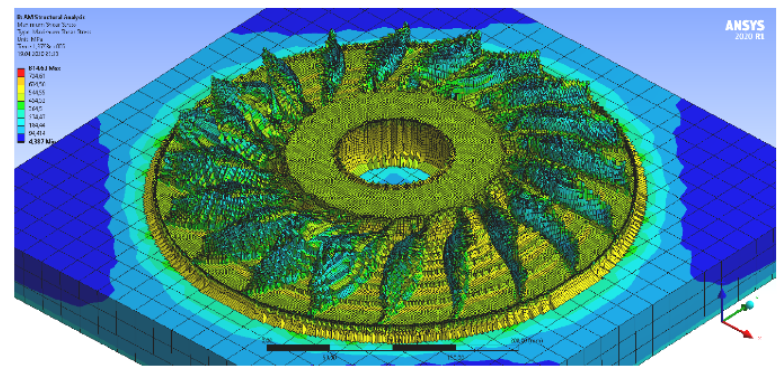

Fig. 6. Shear stress field in dangerous section in the most loaded section

The value of the printing inaccuracy at an angle of the laser direction of $45^{\circ}$ is in the range of $-1.8 \ldots+1.8 \mathrm{~mm}$ (in the support zone) and $-0.2 \ldots+0.2 \mathrm{~mm}$ (in the area of the main part) therefore the error of the deformation of the location neglect (less than $3 \mathrm{~mm}$ for support) the amount of deformation error see in Figure 7. 


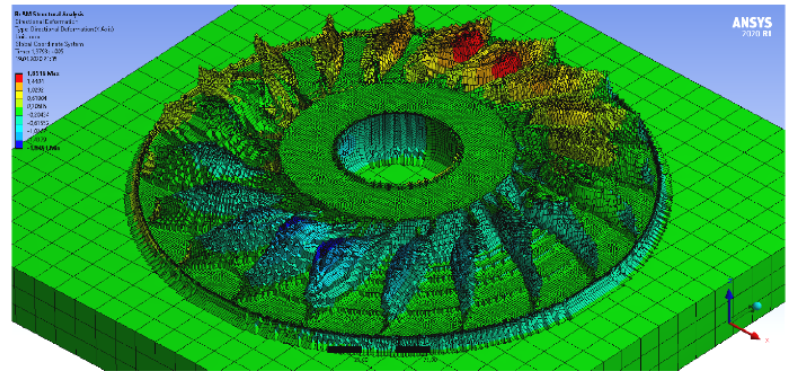

Fig. 7. The deformation field of the location in the most loaded section

The density of the grid is $2 \cdot 10^{6}$ knots, such a small grid allows to assert the validity of the obtained results by FEM methods. According to the results of the calculation, the need to create a base for printing - steel 40XS or analogues, the creation of reinforcing supports (due to the complex geometry of the main blades, the angle of inclination when printing is greater than $70^{\circ}$ ).

When loading an archive with geometry (.stl) of the finite element grid and initial conditions, we obtain a control program for additive production on a standard installation. The conclusion of this calculation is a ready-made control program for printing, data indicating the possibility and safety of printing the impeller in the case of titanium Ti64.

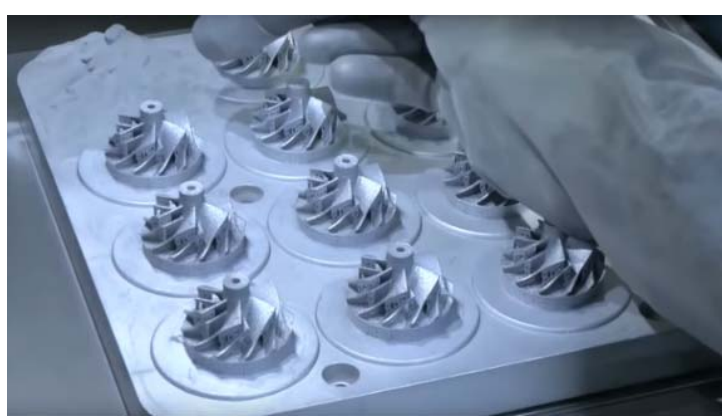

Fig. 8. Cleaning of the printed centrifugal impellers from powder

As a result of experiments with baking of Ti64 powder, the quality of the surface was determined, which, although it contains a large number of small deformation elements, but their effect on mechanical characteristics is not large [4], thus, none of these is a large stress concentrator and will not lead to destruction. as a result of the action of workloads. The titanium alloy Ti6-Al-4V under normal conditions (Fig. 9) exists in the form of an alpha phase with a crystal structure of densely paved spheres. The beta phase has a cubic crystal structure. Aluminum stabilizes the alpha phase and vanadium the beta phase [9]. The dependence of the number of granules per unit area on their diametrical size can be seen in Figure 10.

Analysis of the size distribution of Ti64 / Ti6-Al-4V powder granules (Fig. 10) shows that it obeys Gau'sss law, the most probable granule size being $5.1 \ldots 5.3 \mathrm{~nm}$. Analysis of the microstructure of the samples obtained by additive technologies showed the presence of a small number of pores (Fig. 9b). In the future, real tests of samples are planned.

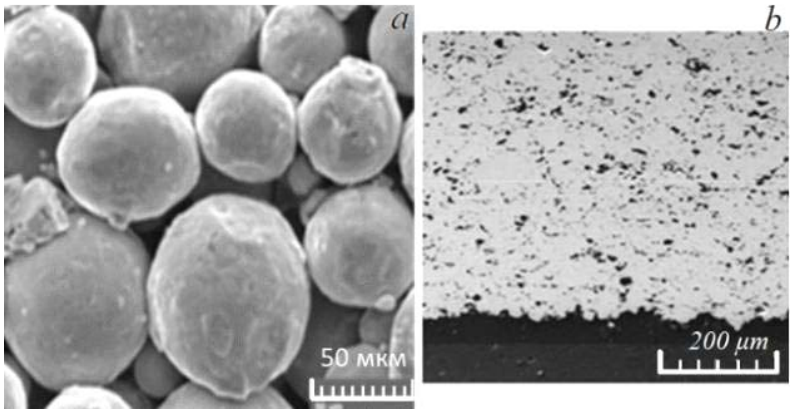

Fig. 9. Ti64 / Ti6 - $\mathrm{Al}-4 \mathrm{~V}$ powder in the form of granules (a) and the layer structure of Ti64 powder as a result of sintering (b)

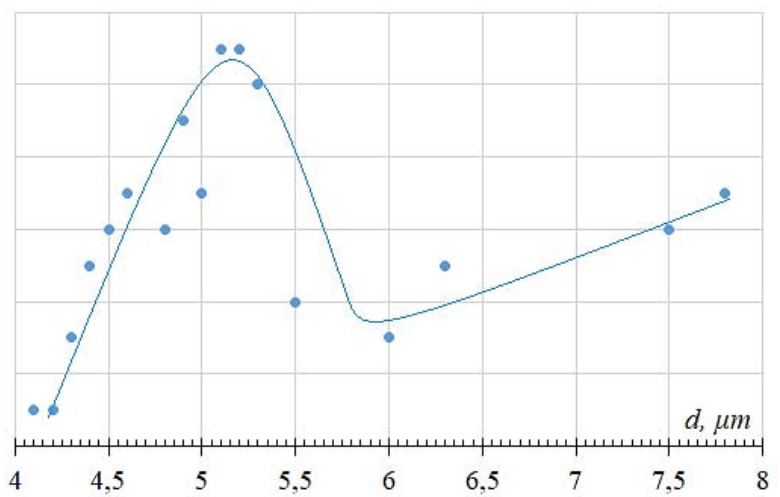

Fig. 10. Distribution by size of granules

\section{Conclusions}

1. Additive method of production is considered more appropriate for the production of centrifugal impellers and blades due to the presence in the geometry of the latter complex surfaces of triple curvature, difficult to machine or cannot be obtained mechanically due to small size tolerances (thinnest parts of splitting blades $1.6 \mathrm{~mm}$ )

2. According to the analysis of the calculation of the additive seal of the wheel, the economy of the material is determined in comparison with the processes of chip formation, which reaches $300 \ldots 400 \%$.

3. Centrifugal fans, due to the design features of units and aggregates are monolithic, so in the production process are adversely affected by a large number of roughing and finishing operations, which adversely affect their structure and quality. Mechanical exposure can leave surface defects. Additive technologies depend only on the type of sintering or surfacing mechanism and are more permanent in the end. The obtained surface quality on a simple printer is satisfactory for the conditions of nominal operation of the unit (absence of stress concentrators that can lead to failure and the value of equivalent roughness, which lies within the necessary limits for proper and stable air or liquid flow).

4. Due to the use of spatial printing, the percentage of marriage decreased from the range of $75 \ldots 85 \%$ to $3 \ldots 10 \%$, which according to the calculations in the first approximation, given the increase in energy consumption and its reduction in material consumption, gives an increase in productivity of $877 \%$. The need to create a printing base and supporting elements is justified.

5. Deformations as a result of local temperature 
stresses lie within the tolerances.

6 . The additive method allows to obtain all the necessary number of working elements in all types of production, from experimental to mass without a sharp rise in price. Machines with laser installations are universal, which indicates their ability to be used later in the manufacture of other parts of a completely new configuration.

7. The cost of preparing a part for production is simplified, as it is not necessary to adjust the CNC machine, only a CAD model is needed for printing, which is transferred to printing in an incredibly fast time (recommended check of the thermodynamic model).

\section{References}

1. Исследование свойств коррозионностойкой стали, полученной по аддитивной технологии, применительно к условиям эксплуатации жидкометаллических теплообменных систем. Перспективные материалы / Ладыко М. А., Люблинский И. Е., Еремин А. Г. и др. 2019. - № 10. - С. 26-34.

2. Воронецкий А. В. Современные центробежные компрессоры / Воронецкий А. В. - М. : Премиум Инжиниринг, 2007.

3. Чемодуров А. Н. Применение аддитивных технологий в производстве изделий машиностроения /
Чемодуров А. Н. // Известия ТулГУ. Технические науки. - 2016. - № 8. - Ч. 2. - С. 210-217.

4. Смуров И. Ю. О внедрении аддитивных технологий и производства в отечественную промышленность / Смуров И. Ю., Конов С. Г., Котобан Д. В. // Новости материаловедения. Наука и техника. - 2015. - № 2. C. $11-22$.

5. Чумаков Д. М. Перспективы использования аддитивных технологий при создании авиационной и ракетно-космической техники / Чумаков Д. М. // Труды МАИ. - 2014. - № 78. - 22 с.

6. Логачева А. И. Аддитивные технологии производства ответственных изделий из металлов и сплавов / Логачева А. И., Сентюрина Ж. А., Логачев И. А. // Перспективные материалы, 2015. - № 4. - С. 5-16.

7. Бобровский С. А. Гидравлика, насосы и компрессоры / Бобровский С. А., Соколовский С. М. - М., изд-во «Недра», 1972.

8. Михайлов А. К. Компрессорные машины / Михайлов А. К., Ворошилов В. П. - М. : Энергоатомиздат, 1989.

9. Titanium Alloy Ti 6Al-4V Technical Data Sheet. Carpenter Technology Corporation, 2017.

Одержано 23.07.2021

Татарчук Т. В., Кравчук Ю. С. Пелих В. П. Використання адитивних технологій при виготовленні відцентрових робочих коліс

Мета роботи. Аналіз методів виготовлення відцентрових лопаток методами 3D друку на прикладі модернізованої системи охолодження двигуна АI-450М гелікоптеру Мi-2МСБ.

Методи дослідження: розрахунковий метод кінцевих елементів, аналітичний.

Отримані результати. Проведені дослідження показали, щуо застосування технологій пошарового друку відиентрового колеса системи охолодження надають наступні можливості та покращення:

- зменшити відсоток відбракування готових виробів у 8-9 разів;

- знизити витрату матеріалу на 300-400\%;

- підвищитти швидкість виробництва, дослідів, експериментів та відпрацювання виготовлення робочих елементів за рахунок розробки нових технологій швидкого виробництва (rapid fabrication);

- легкий друк раніше «неможливої» геометрії.

Був проведений аналіз можливих видів виготовлення робочого відиентрового колеса, в роботі проведена розрахункова оцінка термодинамічних параметрів в прочесі поетапного нанесення шарів металу. Проблема великого відсотку браку в процесі класичного - механічного фрезерування лопатей була вирішена за рахунок зміни виду виробництвва на адитивний.

Наукова новизна. У сучасному світі за рахунок розповсюдження CAD / CAM / CAE / PLM технологій та накопиченню широкої бібліотеки матеріалів відкривається велика кількість новітніх та більш ефективних, 3 точки зору економії та якості, методів виготовлення вузлів та агрегатів. На прикладі таких гігантів виробництвв авіаційних двигунів Rolls-Royce Motor, General Electric ma Pratt \& Whitney зрозуміло, щуо використання та розробка новітніх методів об'ємного друку є доиільною.

Практична чінність. Одержані результати мають важливе значення в подальшому процесі виробництва та модернізачії гелікоптеру Мі-2 усіх модифікаиій з новітніми двигунами, а також для проектів по розвитку будівництва гелікоптерів Украӥні-МСБ-2 «Надія», МСБ-6 «Отаман», МСБ-8 та інших. Можливість підвищення ефективності виготовлення основних робочих елементів - лопатей дає змогу знизити собівартість вузлів, їх подальшого ремонту, експлуатащії. Найголовнішим чинником є підвищення надійності, тай як при виготовленні знижується ймовірність дефектів, щзо потім не будуть виявлені на етапах проміжного та кінцевого контролю.

Ключові слова: адитивні технологіі (AT), 3D друк, пошарове нарощування, відцентрове колесо (ВК), метод кінцевих елементів (МКЕ), система охолодження (СО), модернізація, повітряна система, пневмосистема, авіаційний компресор. 
Татарчук Т. В., Кравчук Ю. С. Пелых В. П. Использование аддитивных технологий при изготовлении центробежных рабочих колес

Цель работы. Анализ методов изготовления иентробежных лопаток методами 3D печати на примере модернизированной системы охлаждения двигателя АИ-450М вертолета Ми-2МСБ.

Методы исследования: расчетный метод конечных элементов, аналитический.

Полученные результаты. Проведенные исследования показали, что применение технологий послойного печати иентробежного колеса системы охлаждения предоставляют следующие возможности и улучшения:

- уменьшить процент отбраковки готовых изделий в 8-9 раз;

- снизить расход материала на 300-400\%;

- повысить скорость производства, опытов, экспериментов и отработки изготовления рабочих элементов за счет разработки новых технологий быстрого производства (rapid fabrication)

- легкая печать ранее «невозможной» геометрии.

Был проведен анализ возможных видов изготовления рабочего иентробежного колеса, в работе проведена расчетная оценка термодинамических параметров в проиессе поэтапного нанесения слоев металла. Проблема большого прочента брака в процессе классического - механического фрезерования лопастей была решена за счет изменения вида производства на аддитивный.

Научная новизна. В современном мире за счет распространения CAD / CAM / CAE / PLM технологий и накоплению широкой библиотеки материалов открывается большое количество новых и более эффективных, $c$ точки зрения экономии и качества, методов изготовления узлов и агрегатов. На примере таких гигантов производства авиационных двигателей Rolls-Royce Motor, General Electric u Pratt \& Whitnеy понятно, что использование и разработка новейших методов объемного печати целесообразна.

Практическая ченность. Полученные результаты имеют важное значение в дальнейшем прочессе производства и модернизации вертолета Ми-2 всех модификаџий с новейшими двигателями, а также для проектов по развитию вертолетостроения в Украине - МСБ-2 «Надежда», МСБ-6 «Атаман», МСБ-8 и других . Возможность повышения эффективности производства основных рабочих элементов - лопастей позволяет снизить себестоимость узлов, их последующего ремонта, эксплуатации. Самым главным фактором является повышение надежности, да как при изготовлении снижается вероятность дефектов, потом не будут обнаружены на этапах промежуточного и конечного контроля.

Ключевые слова: аддитивные технологии (АД), 3D печать, послойное наращивание, иентробежное колесо (BК), метод конечных элементов (МКЭ), система охлаждения (СО), модернизация, воздушная система, пневмосистема, авиационый компрессор. 